\title{
Proliferation of Nuclear Weapons
}

\section{Theodore B. Taylor}

Chairman, NOVA, Damascus, Maryland. Dr. Taylor, a former nuclear weapons designer, received the US Atomic Energy Commission's 1965 Lawrence Memorial Award and was Deputy Director of the Defense Nuclear Agency. He is a Fellow of the American Physical Society.

Nuclear proliferation is greatly enhancing the likelihood of nuclear war. It dramatically increases the number of scenarios for small-scale nuclear wars or nuclear terrorism, that could escalate to nuclear war between the superpowers. Deterrence, the cornerstone of national security in present strategies, fails against nuclear terrorism simply because there are no welldefined targets against which to retaliate.

\section{Proliferation among Nations}

Any determined nation could develop and start stockpiling reasonably efficient and reliable nuclear weapons within ten years and, in many cases, in a much shorter time. The knowledge, nonnuclear materials, and components needed for the production of nuclear weapons are accessible worldwide. (1) The main technical barrier is obtaining the required nuclear material (highly enriched uranium or plutonium), but even that is not much of a barrier today.

Detailed information needed to design facilities for producing nuclear weapon materials is public. Key components of such facilities can be purchased through international markets. Using plutonium extracted from spent fuel from nuclear reactors is also open to any country that has a 


\section{2 / Inevitability}

civilian reactor or high-power research reactor. Another alternative, applicable to at least a dozen nations, is the diversion of highly enriched uranium or plutonium from other types of research facilities. These often contain enough material for at least several nuclear weapons.

There are several ways that present safeguards against diversion of nuclear material from nonmilitary reactors and their supporting facilities could be defeated. These facilities produce nuclear material suitable for use in weapons and many, allegedly used for peaceful purposes, are not subject to proliferation safeguards of the International Atomic Energy Agency (IAEA). Further, even where IAEA safeguards do apply, they cannot detect diversion of small amounts of nuclear material and, at many facilities, the annual threshold of detection is significantly greater than the amount of material needed for a nuclear explosive. In addition, even nations currently adhering to international safeguards can break the agreement at a later date if the nation decides its vital interests so dictate, for example if the nation is losing a conventional war.

"By the year 2000, there will be more than 3 million

kilograms of plutonium in the world, enough for at least 500,000 nuclear weapons."

Even where there is no current diversion of nuclear materials, the worldwide spread of plutonium produced in civilian nuclear power reactors has produced "latent proliferation" — the ability to produce nuclear weapons in short order - in every country with a nuclear power plant. Nuclear explosives can be made with less than 6 kilograms of plutonium (1), in size about enough to fill a coffee cup. The world's present inventory of plutonium produced in civilian reactors is roughly 700,000 kilograms, greater than the total amount in the world's nuclear arsenals. This plutonium is being produced in thirty-six countries. By the year 2000, there will be more than 3 million kilograms of plutonium in the world, enough for at least 500,000 nuclear weapons. (2)

The plutonium produced in a reactor must be separated before it can be used in a weapon. While commercial facilities are more complex, a separation plant suitable for military purposes can be built for less than $\$ 50$ million in several months time. (3) Every nation with a commercial nuclear power plant has such resources, since they are small compared with those needed for acquiring the power plant itself. Each year, the reprocessing plant can extract approximately 250 kilograms of plutonium from a single commercial reactor, enough for forty nuclear weapons at the very least. 
To summarize the point: The most difficult technical barrier for the production of nuclear weapons is access to the required nuclear material. But thirty-six countries with nuclear power plants produce at least enough plutonium for forty nuclear weapons per year from each such plant.

It is also possible that international illegal markets in nuclear weapon materials or, conceivably, in complete nuclear weapons, may develop in the future, as they have for a wide variety of other weapons in the past. As with other weapons, the illegal suppliers of such materials could be criminals who steal the materials or act as middlemen between illegal suppliers and the buyer.

\section{The Psychology of National Proliferation}

As long as nations possessing nuclear weapons continue to behave as though they feel more secure with than without them, more nonnuclear states can be expected to join "the nuclear club." The danger of proliferation to the Indian subcontinent illustrates the psychology behind the phenomenon and how proliferation spreads like an epidemic. In 1945, near the end of World War II, the United States exploded its first nuclear weapon. In the tense East-West relations of the postwar period, the Soviet Union detonated its first weapon in 1949. As relations between the Soviet Union and China chilled in the 1960s, China conducted its first nuclear test in 1964. In its turn, India, which had fought a border war with China in 1962, then conducted a nuclear test in 1974.

Although India's nuclear test was claimed to be for peaceful purposes, and it has repeatedly denied having any nuclear weapons, there is no question that India could quickly produce deliverable nuclear weapons at any time it so desired. In response, India's traditional enemy, Pakistan, has pushed its own nuclear program to the point where, probably, it too can make nuclear weapons any time it desires. (4) Proliferation enters a new, ironic phase with India now considering production of nuclear weapons in response to their possible acquisition by Pakistan.

The Middle East is another area with high danger of proliferation. There have been strong indications that, in spite of official denials, Israel has been producing nuclear weapons since the late 1960s. Convincing public revelations by a former employee of the Israeli nuclear establishment in the fall of 1986 leave little doubt that Israel has a substantial stockpile of nuclear weapons, credibly more than a hundred. (5) This creates an atmosphere in which the Arab nations can easily justify their own attempts at developing nuclear weapons. In fact, the 1981 Israeli air raid on the Iraqi research reactor at Osirak (Tammuz) was motivated by fear it would be used as a source of materials for nuclear weapons. 


\section{4 / Inevitability}

Proliferation is also encouraged by the fact that nearly fifty nations including Argentina, Brazil, Chile, China, France, India, Israel, Pakistan, Portugal, Saudi Arabia, South Africa, Spain, and Vietnam - have not signed the Non-Proliferation Treaty. The US and the USSR were required by Article VI of the treaty "to pursue negotiations in good faith on effective measures relating to cessation of the nuclear arms race at an early date and to nuclear disarmament." Yet since the treaty went into effect in 1970, the American strategic nuclear arsenal has grown from 4,000 warheads to 12,000 and the Soviet arsenal has increased from 2,000 to 10,000. $(6,7)$

“... as long as we believe nuclear weapons are an important

part of our security, we cannot expect the rest of the world to think or act differently."

We, in the US and the USSR, may feel powerless to stop proliferation since the parties involved are not under our direct control. But, as long as we believe nuclear weapons are an important part of our security, we cannot expect the rest of the world to think or act differently. If we succeed in changing our own behavior, there is hope for the rest of the world. If we do not, we have no one to blame but ourselves as nuclear weapons proliferate.

\section{Nuclear Terrorism}

Proliferation of nuclear weapons among nations is terrifying enough. But, starting in the mid-1960s, there has been a steadily increasing concern that nonnational organizations might acquire nuclear weapons. Such organizations include established terrorist organizations; new terrorist groups, possibly including criminals planning to use the weapons for extortion; and desperate factions of an established government during a coup. An extensive and detailed expression of this concern and possible ways for alleviating it has recently been published by the International Task Force on Prevention of Nuclear Terrorism. (1)

The most straightforward way for terrorists to acquire nuclear weapons would be to steal complete weapons from military facilities or transport vehicles. The terrorist's job is complicated somewhat because many weapons are protected by Permissive Action Links (PALs). PALs are like combination locks which prevent the weapon from being detonated until the correct secret access code ("combination") has been entered. Some PALs go further and are designed to make the nuclear weapon inoperable after any unsuccessful attempt to bypass the PAL.

While detailed assessment of the effectiveness of PALs is classified info- 
rmation, they are not an insurmountable obstacle. Organizations with access to skilled technicians (internal or hired) could disassemble the stolen weapon and build a new one detonated in a different way. And smart terrorists would focus on weapons that are not protected.

Terrorist organizations could also construct a nuclear weapon from scratch. As with nations, the main technical barrier is the acquisition of the required plutonium or highly enriched uranium. This material could be obtained by theft, by "donation" from a nation sympathetic to the terrorists, or by purch-asing it on a black market.

The problem of theft brings out an important difference in protecting against national versus terrorist diversion of nuclear materials. In the case of national diversion, only detection is required. But in the case of terrorist diversion, strong physical security is also needed since terrorists or criminals might obtain material through a physical attack. While the details of the physical security mechanisms to counteract such threats are classified, what has been publicly revealed tends not to inspire confidence. It is highly doubtful that the physical security afforded to plutonium and highly enriched uranium would be effective against thefts involving the sophistication displayed in many modern thefts of money or other materials less valuable than a nuclear weapon; the value of stolen nuclear materials would be measured in millions of dollars and a complete weapon would be worth many times more.

\section{"The most straightforward way for terrorists to acquire nuclear weapons would be to steal complete weapons from military facilities or transport vehicles."}

Whether they obtain nuclear material by theft, diversion, or purchase on a black market, nuclear terrorists would require less material if they could obtain metallic plutonium or highly enriched uranium rather than the more commonly available plutonium oxide or uranium oxide. Even if an organization only had access to the oxides, weapons in the kiloton range could still be made. While they would require several times as much material and would be less reliable than weapons made from metallic material, with proper design they still would present an awesome threat. (1)

Although, to date, there has been no reported evidence of nuclear weapons possession by terrorist organizations, the likelihood of nuclear terrorism is increasing for several reasons. The incidence, sophistication, and lethality of acts of "conventional" terrorism have increased dramatically in recent years. There is growing evidence of state support, or even sponsorship, of terrorist groups (one nation's "freedom fighters" are 
often another's terrorists). Nuclear weapons are often stored and deployed in areas of increasing terrorist activity. The number of places where nuclear weapon materials or assembled military nuclear weapons are in storage or in transport are increasing. Several hundred threats of nuclear terrorism based on claimed possession of at least one nuclear explosive have been investigated by authorities and found to be hoaxes. Some of these threats have been credible enough to cause serious concern.

\section{Conclusion}

Nuclear proliferation - be it among nations or terrorists - greatly increases the chance of nuclear violence on a scale that would be intolerable. Proliferation increases the chance that nuclear weapons will fall into the hands of irrational people, either suicidal or with no concern for the fate of the world. Irrational or outright psychotic leaders of military factions or terrorist groups might decide to use a few nuclear weapons under their control to stimulate a global nuclear war, as an act of vengeance against humanity as a whole. Countless scenarios of this type can be constructed.

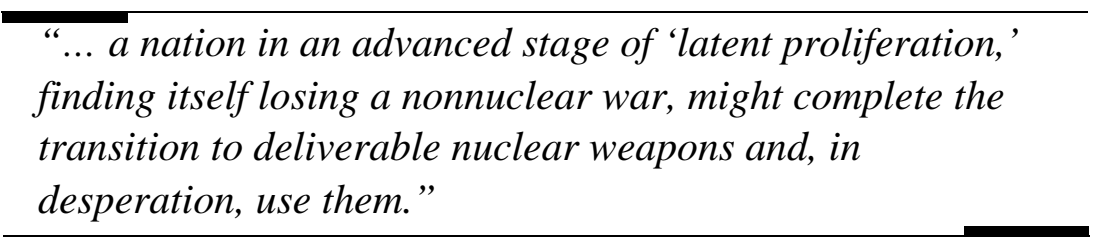

Limited nuclear wars between countries with small numbers of nuclear weapons could escalate into major nuclear wars between superpowers. For example, a nation in an advanced stage of "latent proliferation," finding itself losing a nonnuclear war, might complete the transition to deliverable nuclear weapons and, in desperation, use them. If that should happen in a region, such as the Middle East, where major superpower interests are at stake, the small nuclear war could easily escalate into a global nuclear war.

A sudden rush of nuclear proliferation among nations may be triggered by small nuclear wars that are won by a country with more effective nuclear forces than its adversary, or by success of nuclear terrorists in forcing adherence to their demands. Proliferation of nuclear weapons among nations could spread at an awesome rate in such circumstances, since "latent proliferation" is far along in at least several dozen nations, and is increasing rapidly as more nuclear power plants and supporting facilities are built in more countries.

In summary, much more serious international attention than is now evident needs to be given to the consequences of nuclear proliferation among nations, terrorists, or criminals. Continuing to neglect this menace is a recipe for disaster. 


\section{References}

1. J. Carson Mark, Theodore Taylor, Eugene Eyster, William Maraman, and Jacob Wechsler, "Can Terrorists Build Nuclear Weapons?" in Paul Leventhal and Yonah Alexander, eds., Preventing Nuclear Terrorism, Report of the International Task Force on Prevention of Nuclear Terrorism (Lexington, Massachusetts: Lexington Books, 1987), pp. 55-66.

2. David Albright, "Civilian Inventories of Plutonium and Highly Enriched Uranium," in Leventhal and Alexander, pp. 263-297.

3. John R. Lamarsh, "Dedicated Facilities for the Production of Nuclear Weapons in Small and/or Developing Nations," Appendix VI-A, in Nuclear Proliferation and Safeguards, Appendix Volume II, Part Two, Office of Technology Assessment, Congress of the United States (Washington, D.C.: Government Printing Office, June 1977), pp. VI-35-42.

4. Warren Donnelly, et al., Updated "Issue Briefs" on Foreign Nuclear Programs, Environment and Natural Resources Policy Division,

Congressional Research Service (Washington, D.C.: US Library of Congress, 1987).

5. Sunday Times (London), October 5, 1986, pp. 1-3.

6. Tom Gervasi, America's War Machine: The Pursuit of Global Dominance (New York: Grove Press, 1985), pp. 85, 88.

7. Bulletin of the Atomic Scientists, Vol. 43 No. 4 (May 1987), p. 57. 